\title{
Interleukin-6 increases insulin secretion and preproinsulin mRNA expression via $\mathrm{Ca}^{2+}$-dependent mechanism
}

\author{
H Shimizu, K Ohtani, Y Kato ${ }^{1}$ and M Mori \\ The First Department of Internal Medicine, Gunma University School of Medicine, Maebashi, Japan \\ ${ }^{1}$ Biosignal Research Center, Institute for Molecular and Cellular Regulation, Gunma University, Maebashi, Japan \\ (Requests for offprints should be addressed to H Shimizu, First Department of Internal Medicine, Gunma University School of Medicine, \\ 3-39-22 Showa-machi, Maebashi, Gunma 371 Japan; Email: hshimizu@akagi.sb.gunma-u.ac.jp)
}

\begin{abstract}
Interleukin (IL)-6, one of the cytokines released from inflammatory cells, stimulates insulin secretion in a physiological concentration $(1-100 \mathrm{pg} / \mathrm{ml})$, but the exact mechanism is still unknown. The present studies were undertaken to investigate the mechanism of IL-6-induced stimulation of insulin secretion in HIT-T 15 cells. The effects of the addition of nifedipine on the IL-6 (100 pg/ $\mathrm{ml}$ )-induced stimulation of insulin secretion were investigated. We also examined the possibility that IL-6 (1$100 \mathrm{pg} / \mathrm{ml}$ ) may stimulate insulin messenger ribonucleic acid (mRNA) expression, using the reverse transcriptionpolymerase chain reaction method. The addition of 100 and $1000 \mathrm{nM}$ nifedipine significantly attenuated the stimulatory effects of $100 \mathrm{pg} / \mathrm{ml} \mathrm{IL-6}$ on insulin secretion.
\end{abstract}

The addition of 1-100 pg/ml IL-6 dose-dependently increased preproinsulin mRNA expression relative to $\beta$-actin mRNA. IL-6 increased insulin gene promoter activity of fragments $\mathrm{A}(-2188$ to $+337 \mathrm{bp})$ and $\mathrm{B}$ $(-1782$ to $+270 \mathrm{bp})$ but not fragments $\mathrm{C}(-1275$ to $+270 \mathrm{bp}), \mathrm{D}(-1138$ to $+270 \mathrm{bp}), \mathrm{E}(-880$ to $+236 \mathrm{bp}$ ) or $\mathrm{F}$ ( -356 to $+252 \mathrm{bp}$ ). The addition of $10 \mathrm{nM}$ nifedipine completely abolished the stimulatory effect of $10-100 \mathrm{pg} / \mathrm{ml} \mathrm{IL-6}$ on relative preproinsulin mRNA expression. These data raised the possibility that IL-6 increased preproinsulin mRNA expression via the stimulation of $\mathrm{Ca}^{2+}$ influx which enhances insulin gene expression.

Journal of Endocrinology (2000) 166, 121-126

\section{Introduction}

Interleukin (IL)-6, one of the cytokines, is released from invaded inflammatory cells in various acute phase inflammatory responses (Kishimoto et al. 1992). Its complementary DNA has been cloned by Hirano et al. in 1986. Several studies have demonstrated that IL-6 stimulates insulin secretion in HIT-T 15 cells and rat pancreatic islets (Buchard et al. 1990, Sandler et al. 1990, Shimizu et al. 1995a). IL-6 may be involved in the regulation of insulin secretion from pancreatic $\beta$-cells following inflammatory responses. However, the exact mechanism by which IL-6 stimulates insulin secretion still remains to be established.

The expression of hepatic genes is regulated by cytokines during an acute phase inflammatory response (Baumann et al. 1987, Gaudlie et al. 1987). Both IL-1 and IL-6 are major inflammatory cytokines which influence plasma protein gene expression (Baumann et al. 1990). IL-1 $\beta$ has been reported to deplete insulin mRNA by a mechanism dependent on gene transcription and protein biosynthesis, and to increase the heat shock protein hsp 70 in mouse pancreatic islets (Eizirik et al. 1990, Eizirik 1991). However, little is known about the regulation of gene expression by IL-6 in pancreatic $\beta$-cells. There is a possibility that insulin gene expression may also be regulated by IL-6, resulting in an increase in insulin secretion from $\beta$-cells. The present studies were undertaken to investigate the mechanism by which IL-6 stimulates insulin secretion and synthesis in a clonal cell line of hamster $\beta$-cells, HIT-T 15 cells (Santerre et al. 1981).

\section{Materials and Methods}

\section{Chemicals}

IL-6 was obtained from Sigma Immuno Chemicals (St Louis, MO, USA). The powder of the incubation medium $\mathrm{F}-12 \mathrm{~K}$ was purchased from Flow Laboratories, Inc. (Irvine, Scotland). ISOGENE was purchased from Nippon Gene (Tokyo, Japan). Fetal bovine serum was purchased from Gibco (Grand Island, NY, USA). Dimethyl sulfoxide (DMSO), and nifedipine were purchased from Sigma Chemical Co. (St Louis, MO, USA).

\section{Cell culture}

Sixty-two to sixty-five passages of HIT-T 15 cells were purchased from Flow Laboratories, Inc. (McLean, VA, 
USA). The cells were routinely cultured in the F-12 K medium containing $7 \mathrm{mM}$ glucose supplemented with 10\% fetal bovine serum. Insulin secretion from HIT-T 15 cells is glucose-sensitive (Ohtani et al. 1998a). For the studies on insulin secretion, cells were passaged and seeded $\left(10^{5}\right.$ cells per well) in 24 -well multiwell plates. The cells were used for the experiments just before reaching confluence and normally preincubated for $24 \mathrm{~h}$ in the F-12 K medium. On the day of the experiment, the culture medium was aspirated and replaced with medium supplemented with the addition of chemicals as described below.

\section{Experimental protocols}

The $\mathrm{Ca}^{2+}$ channel blocker, nifedipine, dissolved in DMSO, was added in $1 \mathrm{ml}$ of the $\mathrm{F}-12 \mathrm{~K}$ medium to final concentrations of 1 to $1000 \mathrm{nM}$. The cells were incubated for $10 \mathrm{~min}$ prior to the addition of IL-6. The final concentration of DMSO was designed to be below 0.05\% to avoid an influence of osmolarity on insulin secretion. Following the addition of $100 \mathrm{pg} / \mathrm{ml}$ IL-6, cells were incubated for $2 \mathrm{~h}$ at $37^{\circ} \mathrm{C}$. The medium was aspirated and frozen at $-20^{\circ} \mathrm{C}$ until immunoreactive insulin assay.

\section{Preproinsulin messenger ribonucleic acid $(m R N A)$ determination}

The cells were incubated with $1 \mathrm{ml}$ of the $\mathrm{F}-12 \mathrm{~K}$ medium containing $1-100 \mathrm{pg} / \mathrm{ml} \mathrm{IL}-6$ for $2 \mathrm{~h}$ at $37^{\circ} \mathrm{C}$. Following the $2-\mathrm{h}$ incubation, the medium was completely removed and the cells were washed three times with fresh F-12 K medium. Then, the cells were sonicated in $0.8 \mathrm{ml} \mathrm{ISO}-$ GENE and centrifuged at 12000 r.p.m. for $10 \mathrm{~min}$ by microfuge (Sorvall RMC-14). The supernatants containing total RNA were taken from each sample and total RNA was extracted.

Hamster preproinsulin and $\beta$-actin mRNA were measured by the reverse transcription-polymerase chain reaction (RT-PCR) method using a GeneAmp EZ rTth RNA PCR kit (Perkin Elmer, Foster City, CA, USA) as we have previously reported (Ohtani et al. 1998b). The synthetic preproinsulin primer sequences used in the present study were as follows; forward primer: 5'-AGC GTGGCTTCTTCTACACACC-3'; backward primer: 5'-GGTGCAGCACTGATCCACAATG-3', according to the preproinsulin cDNA sequence obtained by Bell and his associates (1979). According to the results from our preliminary experiment confirming the linear increase of PCR products for preproinsulin and $\beta$-actin mRNA, following reverse transcription step at $60{ }^{\circ} \mathrm{C}$ for $30 \mathrm{~min}$, PCR was performed for 32 cycles using a 1-min denaturation step at $94{ }^{\circ} \mathrm{C}$ and $1-$ min annealing-extension step at $60{ }^{\circ} \mathrm{C}$. An additional $7-$ min extension step at $60{ }^{\circ} \mathrm{C}$ was added after the 32 cycles. The PCR product was loaded onto an $8 \%$ acrylamide gel, and intensity of fluorescence of the band stained by ethidium bromide was calculated using the National Institutes of Health Image 1.56 program (Bethesda, MD, USA). The relative expression of preproinsulin mRNA to $\beta$-actin was calculated in each sample.

Next, the cells were incubated with $1 \mathrm{ml}$ of the F$12 \mathrm{~K}$ medium containing $10-100 \mathrm{pg} / \mathrm{ml} \mathrm{IL-6}$ in the presence or absence of $10 \mathrm{nM}$ nifedipine. Following 2-h incubation, the relative preproinsulin mRNA expression was measured by RT-PCR as described above.

\section{Insulin gene promoter assay}

Preproinsulin gene promoter activity was assayed by the method previously reported (Ohtani et al. 1998a). Human insulin gene, which was inserted into pBR 327, was kindly provided by Dr Graeme I Bell (Howard Hughes Medical Institute, The University of Chicago, USA). The fragment lengths and the restriction enzymes used were as follows. Fragment A, 2052 bp ( -2188 to +337 bp), SpeI and DraIII; fragment B, $2052 \mathrm{bp}$ ( -1782 to $+270 \mathrm{bp}$ ), HaeII; fragment C, $1545 \mathrm{bp}$ ( -1275 to $+270 \mathrm{bp}$ ), RsaI and HaeII; fragment D, $1408 \mathrm{bp}(-1138$ to $+270 \mathrm{bp})$, ApaLI and HaeII; fragment E, $1116 \mathrm{bp}(-880$ to +236 bp), NcoI; fragment F, 608 bp ( -356 to -252 bp), HhaI. Each insulin gene fragment was inserted into the SmaI site of a plasmid containing a luciferase gene, Pica gene (Tokyo-Ink, Tokyo, Japan). Plasmid p $\beta$ gal-Control Vector encoding $\beta$-galactosidase gene (Clontech, Palo Alto, CA, USA) was used as the normalization plasmid. Changes of promoter activity were measured by luciferase activity after 24-h incubation with 100 pg/ml IL-6 in F-12 $\mathrm{K}$ medium. The experiment was repeated four times.

\section{Assays}

Immunoreactive insulin concentrations in the incubation medium were assayed by radioimmunoassay using the Phadeceph Insulin Kit (Pharmacia Japan, Tokyo, Japan).

\section{Statistical analysis}

All data are expressed as means \pm S.E. The statistical analysis of the differences of the means was performed by analysis of variance (ANOVA), followed by Duncan's multiple range test for the individual comparisons of the means.

\section{Results}

As shown in Fig. 1, $10 \mathrm{nM}$ nifedipine tended to attenuate the stimulatory effect of $100 \mathrm{pg} / \mathrm{ml}$ IL-6 on insulin secretion. The addition of 100 and $1000 \mathrm{nM}$ nifedipine completely abolished the stimulatory effects of IL-6 on insulin secretion. However, 10-1000 nM nifedipine did not affect 


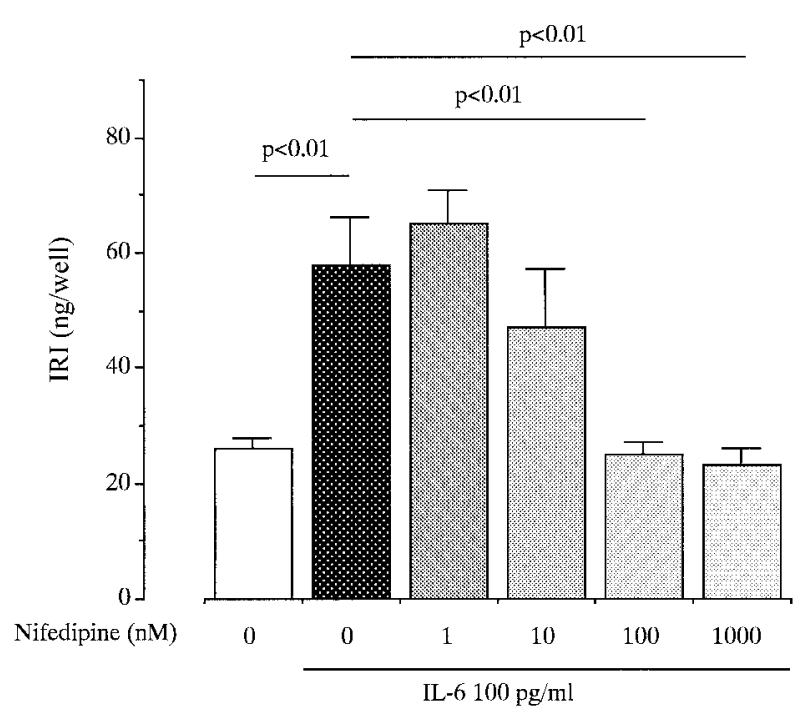

Figure 1 Effect of addition of 1-1000 nM nifedipine on the $100 \mathrm{pg} / \mathrm{ml} \mathrm{IL-6-induced} \mathrm{stimulation} \mathrm{of} \mathrm{immunoreactive} \mathrm{insulin} \mathrm{(IRI)}$ secretion in HIT-T 15 cells. $n=6$ in each group. The experiment was repeated twice.

insulin secretion for $120 \mathrm{~min}$ in HIT-T 15 cells $(0 \mathrm{nM}$, $26 \cdot 0 \pm 1 \cdot 1 \mathrm{ng} /$ well; $10 \mathrm{nM}, 26 \cdot 4 \pm 0 \cdot 4 \mathrm{ng} /$ well; $100 \mathrm{nM}$, $24 \cdot 7 \pm 0 \cdot 4 \mathrm{ng} /$ well; $1000 \mathrm{nM}, 27 \cdot 0 \pm 0 \cdot 6 \mathrm{ng} /$ well, not significant). These data indicated a possible involvement of $\mathrm{Ca}^{2+}$ influx into $\beta$-cells in the effects of IL-6 on insulin secretion.

Figure 2A shows representative PCR products of preproinsulin mRNA and $\beta$-actin mRNA in HIT-T 15 cells. The addition of $1 \mathrm{pg} / \mathrm{ml}$ IL- 6 tended to increase the

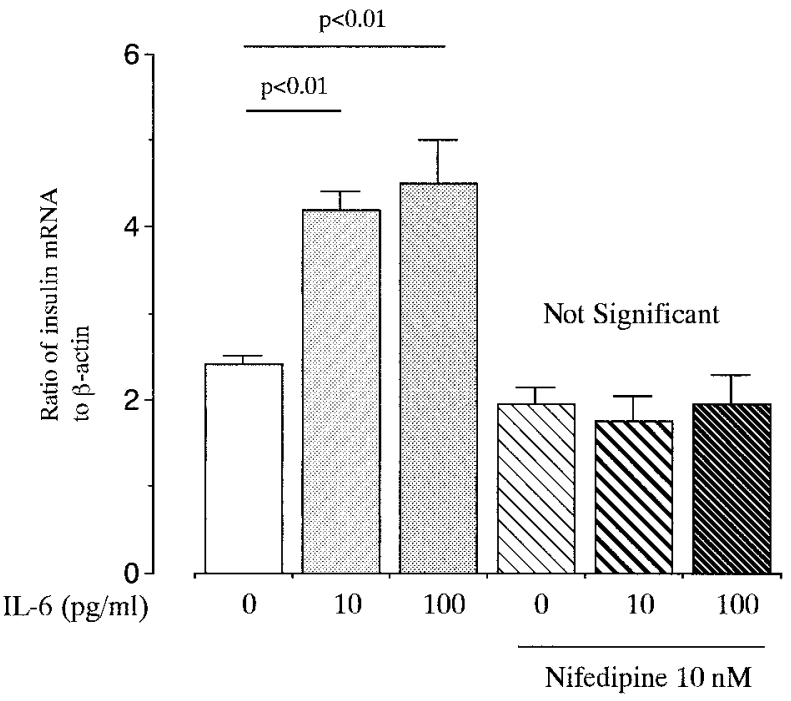

Figure 3 Changes in the effects of IL-6 on preproinsulin mRNA expression relative to $\beta$-actin mRNA expression following nifedipine treatment in HIT-T 15 cells. $n=5$ in each group. The experiment was repeated twice.

preproinsulin mRNA expression relative to $\beta$-actin mRNA in HIT-T 15 cells, and 10 and 100 pg/ml IL-6 significantly increased the relative preproinsulin expression in a dose-dependent manner (Fig. 2B). The addition of $10 \mathrm{nM}$ nifedipine alone did not show a significant effect on the relative preproinsulin mRNA expression but this dose of nifedipine completely abolished the stimulatory effect of $10-100 \mathrm{pg} / \mathrm{ml}$ IL-6 on the relative insulin mRNA expression (Fig. 3).
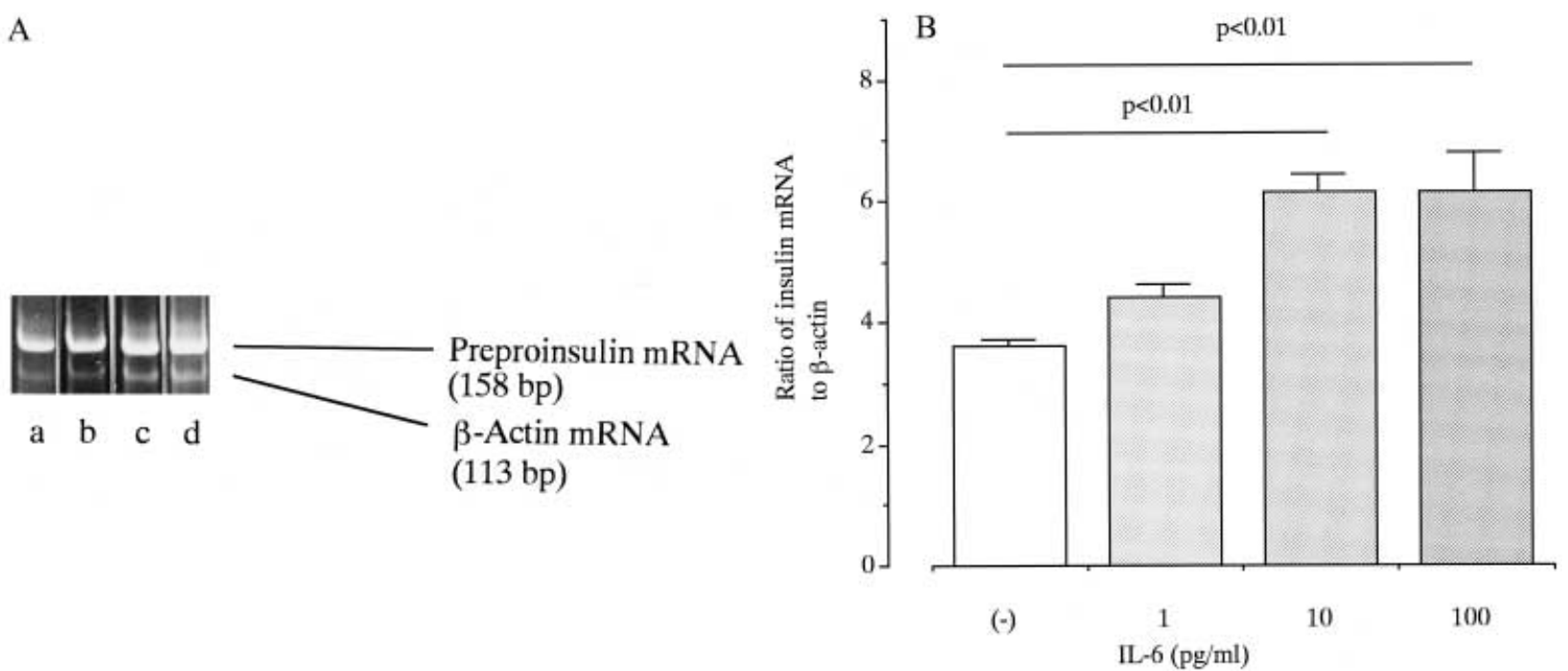

Figure 2 (A) Representative PCR products of preproinsulin mRNA (158 bp) and $\beta$-actin mRNA (113 bp) in HIT-T 15 cells. Lane a, non-IL-6-added control; lane b, 1 pg/ml IL-6; lane c, 10 pg/ml IL-6; lane d, 100 pg/ml IL-6. (B) Changes in preproinsulin mRNA expression relative to $\beta$-actin mRNA expression in HIT-T 15 cells following the addition of IL- $6 . n=5$ in each group. The experiment was repeated twice. 

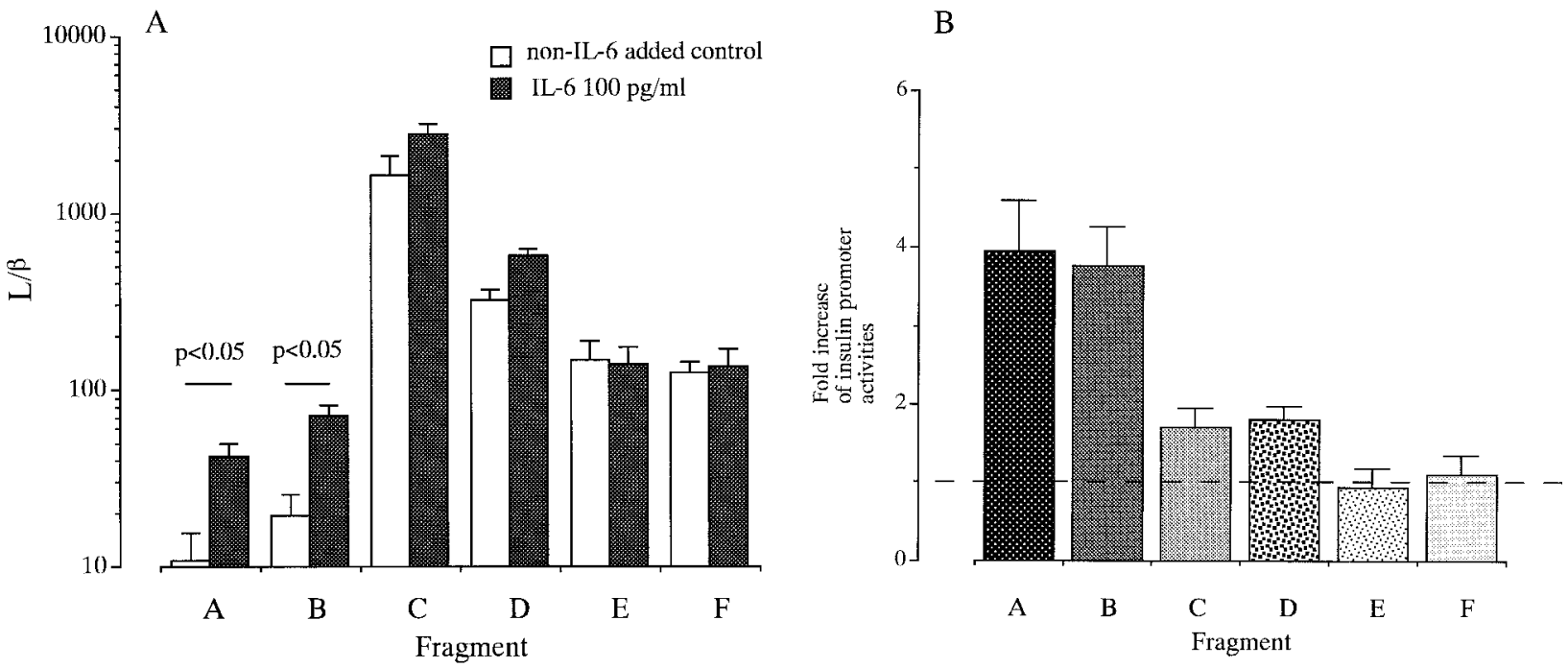

Figure 4 Changes in insulin gene promoter activities, measured by luciferase activities, in each fragment (A) and the fold increase (B) following the addition of $100 \mathrm{pg} / \mathrm{ml} \mathrm{IL-6}$. Each value was the average of values obtained from four separate experiments. The $y$-axis of Fig. $4 \mathrm{~A}$ shows the ratio of luciferase activity against a cotransfected control plasmid $p \beta$ gal-control vector $(\mathrm{L} / \beta) . n=5$ in each group. Dashed line in (B) represents $1 \cdot 0$.

Figure 4 shows changes of insulin gene promoter activities (A) and their fold increase (B) after the addition of $100 \mathrm{pg} / \mathrm{ml} \mathrm{IL-6.} \mathrm{The} \mathrm{addition} \mathrm{of} \mathrm{IL-6} \mathrm{increased} \mathrm{pro-}$ moter activity in fragments $\mathrm{A}$ and $\mathrm{B}$. In contrast, IL-6induced enhancement of promoter activity was not observed with fragments $\mathrm{C}, \mathrm{D}, \mathrm{E}$, and F. This result indicates that portions from $-1782 \mathrm{bp}$ to $-1275 \mathrm{bp}$ are important in the expression of the effect of IL-6 on preproinsulin gene expression.

\section{Discussion}

The present study demonstrated that the addition of IL-6 increased the relative preproinsulin mRNA expression after 2 -h incubation. It is speculated that IL-6 dosedependently stimulates preproinsulin gene expression, resulting in an increase in insulin secretion in HIT-T 15 cells. The addition of nifedipine significantly antagonized the stimulatory effect of IL-6 on preproinsulin gene expression and secretion, suggesting that changes in intracellular $\mathrm{Ca}^{2+}$ concentrations may be involved in the stimulatory effect of IL-6 on insulin synthesis and secretion.

Previous investigators have shown a stimulatory effect of IL-6 on insulin secretion at pharmacological concentrations $(500-5000 \mathrm{pg} / \mathrm{ml}$ ) (Sandler et al. 1990) or have failed to show a significant effect of IL-6 on insulin secretion (Eizirik et al. 1994). We used lower concentrations of IL-6 in the present studies than those used in previous studies. In our preliminary studies, the stimulatory effects of IL- 6 on insulin secretion decreased at higher concentrations $(1000 \mathrm{pg} / \mathrm{ml})$ in HIT-T 15 cells. The concentration of IL-6 (1-100 pg/ml) employed in this work appears to be within the physiological range according to our previous observations on the serum of humans after interferon administration for chronic active hepatitis C (Shimizu et al. 1995b). Therefore, the present data raise the possibility that IL-6 may affect in vivo insulin synthesis and secretion in acute inflammatory responses.

The regulation of preproinsulin gene expression has not been well established. A recent study demonstrated that insulin gene expression is regulated immediately by the circulating glucose concentration, e.g. hypoglycemia as well as hyperglycemia (Philippe et al. 1994, Redmon et al. 1994, Olson et al. 1998). The present data add a new finding that IL-6, a cytokine, immediately (within $2 \mathrm{~h}$ ) stimulates preproinsulin gene expression in HIT-T 15 cells, perhaps via a $\mathrm{Ca}^{2+}$-dependent mechanism.

IL-6 regulates the expression of three fibrinogen genes and CTGGGA is a consensus hexanucleotide sequence of an IL-6 responsive element in the fibrinogen gene on the basis of sequence comparison of the promoter regions (Liu \& Fuller 1995, Zhang et al. 1995). Signal transducer and activator of transcription (STAT)-3, one of the IL-6activated transcription factors, has been reported to bind a CTGGGAA site in the $\alpha_{2}$-macroglobulin gene, but not in the A $\alpha$-fibrinogen (Liu \& Fuller 1995). However, a STAT binding site is still not known in the insulin gene promoter. 
Our inspection of the promoter region of the preproinsulin gene also revealed two putative consensus sequences of an IL-6 responsive element from -1782 to $-1275 \mathrm{bp}$. In the present studies, we found that IL-6 immediately increased the relative preproinsulin mRNA expression in a dose-dependent manner, in parallel with an increase in insulin secretion for $2 \mathrm{~h}$ (Shimizu et al. 1995a). The promoter activity was increased by IL-6 only by fragments A ( -2188 to $+337 \mathrm{bp})$ and $\mathrm{B}(-1782$ to $+270 \mathrm{bp}$ ), but not by other fragments. These data are compatible with the existence of an IL-6 responsive element in the insulin gene promoter region. It is proposed, therefore, that IL-6 may stimulate preproinsulin gene expression through this part of its promoter region.

Nifedipine (dihydropyridine) is a voltage-dependent $\mathrm{Ca}^{2+}$ channel blocker in pancreatic $\beta$-cells (Malaisse \& Sener 1981). In the present studies, the addition of nifedipine antagonizes the effect of IL-6 on the relative preproinsulin mRNA expression. Possible involvement of the $\mathrm{Ca}^{2+}$ channel on gene transcriptional activities has been reported by previous investigators in other cells (Holdstock et al. 1996, Raymond \& Millhorn 1997, LeHoux \& Lefebre 1998). A recent report also demonstrated that $\mathrm{Ca}^{2+}$ channel blockers decrease the transcriptional response to glucose in transfected primary islet cultures, suggesting that $\mathrm{Ca}^{2+}$ influx may play a critical role in transcription (German et al. 1990). These data indicated that $\mathrm{Ca}^{2+}$ channels may be involved in the regulation of preproinsulin gene transcription via stimuli such as glucose or IL-6. However, further studies are necessary to clarify the interrelation between this promoter activity and the $\mathrm{Ca}^{2+}$-dependent mechanism in the preproinsulin gene, because we could not negate the possibility that reduction of IL-6-induced insulin secretion by nifedipine may contribute to a reduction in insulin gene promoter activity.

It is concluded that IL-6 stimulates preproinsulin gene expression in a dose-dependent manner in HIT-T 15 cells. The present data raised the possibility that IL-6 increases preproinsulin mRNA expression, perhaps via stimulating $\mathrm{Ca}^{2+}$ influx, through its responsive element in the insulin promoter region.

\section{References}

Baumann H, Onorato V, Gauldie J \& Jahreis GP 1987 Distinct sets of acute phase plasma proteins are stimulated by separate human hepatocyte-stimulating factors and monokines in rat hepatoma cells. Journal of Biological Chemistry 262 9756-9768.

Baumann H, Morella KK, Jahreis GP \& Marinkovie S 1990 Distinct regulation of the interleukin-1 and interleukin-6 response elements of the rat haptoglobin gene in rat and human hepatoma cells. Molecular and Cellular Biology 10 5967-5976.

Bell GI, Swain WF, Pictet R, Cordell B, Goodman HM \& Rutter WJ 1979 Nucleotide sequence of cDNA clone encoding human preproinsulin. Nature 282 525-527.
Buchard K, Aaen K, Horn T, van Damme J \& Bendtzen K 1990 Interleukin 6: a functional and structural in vitro modulator of beta-cells from islets of Langerhans. Autoimmunity 5 185-194.

Eizirik DL 1991 Interleukin-1 induces an early decrease in insulin release, (pro)insulin biosynthesis mRNA in mouse pancreatic islets by a mechanism dependent on gene transcription and protein biosynthesis. Autoimmunity 10 107-113.

Eizirik DL, Welsh M, Strandell E, Welsh N \& Sandler S 1990 Interleukin-1 $\beta$ depletes insulin messenger ribonucleic acid and increases the heat shock protein hsp 70 in mouse pancreatic islets without impairing the glucose metabolism. Endocrinology 127 2290-2297.

Eizirik DL, Sandler S, Welsh N, Cetkovic-Cvrlje M, Nieman A, Geller D, Pipeleers DG, Bendtzen K \& Hellerström C 1994 Cytokines suppress human islet function irrespective of their effects on nitric oxide generation. Journal of Clinical Investigation $\mathbf{9 3}$ 1968-1974.

Gaudlie J, Richard C, Harnish D, Lansdorp P \& Baumann H 1987 Interferon $\beta_{2} / \mathrm{B}$-cell stimulatory factor type 2 shares identify with monocyte-derived hepatocyte-stimulating factor and regulates the major acute phase protein response in liver cells. PNAS $\mathbf{8 4}$ 7251-7255.

German MS, Moss LG \& Rutter WJ 1990 Regulation of insulin gene expression by glucose and calcium in transfected primary islet cultures. Journal of Biological Chemistry 265 22063-22066.

Hirano T, Yasukawa K, Harada H, Taga T, Watanabe Y, Matsuda T, Kashiwamura S, Nakajima K, Koyama K, Iwamatsu A, Tsunasawa S, Sakiyama F, Mastui H, Takahara Y, Taniguchi T \& Kishimoto T 1986 Complementary DNA for novel human interleukin (BSF-2) that induces B lymphocytes to produce immunoglobulin. Nature 324 73-76.

Holdstock JG, Aylwin SJ \& Burrin JM 1996 Calcium and glycoprotein hormone alpha-subunit gene expression and secretion in alpha T3-1 gonadotropes. Molecular Endocrinology 10 1308-1317.

Kishimoto T, Akira S \& Taga T 1992 Interleukin-6 and its receptor: a paradigm for cytokines. Sciences 258 593-597.

LeHoux JG \& Lefebre A 1998 Transcriptional activity of the hamster CYP11B2 promoter in NCI-H295 cells stimulated by angiotensin II, potassium, forskolin and bisindolmaleimide. Journal of Molecular Endocrinology 20 183-191.

Liu Z \& Fuller GM 1995 Detection of a novel transcription factor for the $A \alpha$ fibrinogen gene in response to interleukin-6. Journal of Biological Chemistry 270 7580-7586.

Malaisse WJ \& Sener A 1981 Calcium antagonists and islet function. XII. Comparison between nifedipine and chemically related drugs. Biochemical Pharmacology 30 1039-1041.

Ohtani K, Shimizu H, Kato Y \& Mori M 1998a Identification and characterization of a glucose-responsiveness region upstream of human insulin gene in transfected HIT-T 15 cells. Biochemical and Biophysical Research Communications 242 446-451.

Ohtani K, Shimizu H, Sato N \& Mori M 1998 b Troglitazone (CS-045) inhibits $\beta$-cell proliferation following stimulation of insulin secretion in HIT-T 15 cells. Endocrinology 139 172-178.

Olson LK, Qian J \& Poitout V 1998 Glucose rapidly and reversibly decreases INS-1 cell insulin gene transcription via decrements in STF-1 and C1 activator transcription factor activity. Molecular Endocrinology 12 207-219.

Philippe J, Pacheco I \& Meda P 1994 Insulin gene transcription is decreased rapidly by lowering glucose concentrations in rat islet cells. Diabetes 43 523-528.

Raymond R \& Millhorn D 1997 Regulation of tyrosine hydroxylase gene expression during hypoxia: role of $\mathrm{Ca}^{2+}$ and PKC. Kidney International 51 536-541.

Redmon JB, Towle HC \& Robertson RP 1994 Regulation of human insulin gene transcription by glucose, epinephrine, and somatostatin. Diabetes 43 546-551. 
Sandler S, Bendtzen K, Eizirik DL \& Welsh M 1990 Interleukin-6 affects insulin secretion and glucose metabolism of rat pancreatic islets in vitro. Endocrinology 126 1288-1294.

Santerre RF, Cook RA, Crisel R, Sher JD, Schmidt RJ, Williams DC \& Wilson CP 1981 Insulin synthesis in a cloned beta cell line of simian virus 40-transfected hamster pancreatic beta cells. PNAS 78 4339-4343.

Shimizu H, Sato N, Tanaka Y, Ohtani K, Fukatsu A \& Mori M 1995a Interleukin-6 stimulates insulin secretion in HIT-T 15 cells. Hormone and Metabolic Research 27 37-38.

Shimizu H, Ohtani K, Sato N, Nagamine T \& Mori M 1995 b Increase in serum interleukin-6, plasma ACTH and serum cortisol levels after systemic interferon- $\alpha$ administration. Endocrine Journal 42 551-556.

Zhang Z, Fuentes NL \& Fuller GM 1995 Characterization of the IL-6 responsive elements in the $\gamma$ fibrinogen gene promoter. Journal of Biological Chemistry 270 24287-24291.

Received 15 February 1999

Revised manuscript received 20 September 1999 Accepted 28 February 2000 